\title{
Howard Nye: \\ Technological Displacement and the Duty to Increase Living Standards: from Left to Right
}

\begin{abstract}
:
Many economists have argued convincingly that automated systems employing present-day artificial intelligence have already caused massive technological displacement, which has led to stagnant real wages, fewer middleincome jobs, and increased economic inequality in developed countries like Canada and the United States. To address this problem various individuals have proposed measures to increase workers' living standards, including the adoption of a universal basic income, increased public investment in education, increased minimum wages, increased worker control of firms, and investment in a Green New Deal that will provide substantial employment in transitioning to green energy, buildings, and agriculture. In this paper I argue that both left-wing and right-wing positions in political philosophy, such as John Rawls's Justice as Fairness and Robert Nozick's Entitlement Theory, are committed to the conclusion that we should take political action to counteract the effects of technological displacement by undertaking such measures to increase workers' living standards.
\end{abstract}

\section{Keywords:}

Ethics and Artificial Intelligence, Environmental Ethics, Political Philosophy, Green New Deal, Universal Basic Income, Workers' Co-ops, Rawls, Nozick, Justice as Fairness, Libertarianism

\section{Outline:}

1. The Great Displacement as the Most Pressing Immediate Ethical Issue with AI Systems ....... 2

2. The Philosophical Positions: From Right to Left ........................................................................ 4

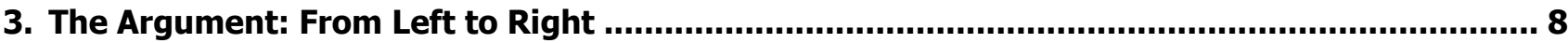

4. Conclusion: How AI can Aid the Solution of its Own Greatest Immediate Problem ................ 12

\section{Author(s):}

Howard Nye:

- Associate Professor of Philosophy, University of Alberta, Department of Philosophy, 2-59 Assiniboia Hall, University of Alberta; Edmonton, AB, Canada, T6G 2E7

- $\quad$ F +1 - 780 - 492 - 3307, $ه$ hnye@ualberta.ca, 邑 https://www.ualberta.ca/arts/about/peoplecollection/howard-nye 


\section{The Great Displacement as the Most Pressing Immediate Ethical Issue with Al Systems}

Lorem There are good reasons to think that the most pressing immediate ethical issue with artificial intelligence [AI] systems (and automated systems in general) is their technological displacement of workers and the consequent stagnation and decline in workers' living standards. I believe that there are three common ways of thinking about this issue that underestimate its immediate practical importance. It is often assumed that this displacement will (i) only occur in the future, (ii) only occur as the result of the adoption of more advanced AI systems than we currently have, and (iii) manifest in high levels of unemployment. ${ }^{1}$ But many economists argue that technological displacement been the chief cause of stagnant real wages and attendant social problems over the last 40 years in OECD countries like Canada and the United States. This displacement has occurred as a result of the employment of the technologies of the past 40 years and has resulted in stagnant real incomes and social problems despite the fact that unemployment (especially as standardly measured) has remained relatively low.

For instance, according to Statistics Canada, the average Canadian real wage peaked in 1977 at around $\$ 24$ per hour, and in 2014 was between $\$ 22.70$ and $\$ 24.51$. Since 2016, real Canadian wages have grown by only $0.37 \%$, with declines in blue collar and manufacturing wages of $0.5 \%$, and $1.26 \%$ respectively. Drawing on data from the U.S. Bureau of Labor Statistics, Drew DeSilver of the Pew Research Centre similarly reports that real wages in the United States peaked at $\$ 23.68$ per hour in 1973 , and were only $\$ 22.65$ in 2018 . While real wages have stagnated over this period, official unemployment rates in Canada and the US are relatively low. But labour force participation rates have declined significantly since the early 2000s, and, while a good deal of this is likely due simply to the aging and retirement of the relatively large generation of baby-boomers, some of this appears to be due to labour market exit by displaced workers. Across OECD countries, the share of midskilled, middle-income jobs has declined by $9.5 \%$, while the share of lower-skilled, lower-paying jobs have increased $1.9 \%$ and high skilled jobs increased $7.6 \%$. This period has also seen a great deal of income polarization. For instance, while average and manufacturing real wages have stagnated and declined, topearning Canadians' real wages rose $10.2-11.64 \%$ during this period. ${ }^{2}$

Michael Hicks and Srikant Devaraj estimated that automation-driven increases in productivity are responsible for $88 \%$ of the decrease in manufacturing jobs, and many economists agree that automation has been the major driver of income polarization. ${ }^{3}$ While this automation has created new jobs, these appear primarily to be either low-skilled jobs that pay less than the mid-skilled jobs that have been lost, or to be high-skilled jobs that are inaccessible to blue collar workers. More opportunities are being created for those with greater relevant skills, and their wages are getting bid up. But those with lesser skills are left with fewer and worse-paying options, and their wages are getting bid down. For instance, in the US 94\% of jobs created from 2005 to 2015 were temp or contractor jobs without benefits (Katz and Krueger). Many displaced workers also struggle to find work and drop out of the labour force. For instance, a study by the Manufacturers Alliance for Productivity and

\footnotetext{
${ }^{1}$ See e.g. Brunn and Duka 2018 and certain aspects of the presentations of Rifkin 1995 and Yang 2018 (while in these works Rifkin and especially Yang note the damage technolgical displacement has already done to workers, their emphasis is sometimes on the potential for further damage and mass unemployment in the future.

2 Statistics Canada 2015; United Steel Workers 2019; DeSilver 2018; Trading Economics 2019; Ketcheson et al. 2017 ; OECD 2017.

${ }^{3}$ Hicks and Devaraj 2015; Krusell et al. 2000; Acemoglu and Autor 2011; Green and Sand 2016; OECD 2017; IMF 2017; Tyson and Spence 2017; Acemoglu and Restrepo 2017; Devaraj et al. 2017.
} 
Innovation found that $41 \%$ of displaced manufacturing workers were either still unemployed or had dropped out of the labour market three years after losing their jobs (Meckstroth).

Andrew Yang refers to this 40-year-old worsening of opportunities for mid- and low-skilled workers that has resulted from automation as "the great displacement" (Yang). The social effects of the great displacement have been devastating. It has been estimated that $40 \%$ of Americans and $46 \%$ of Canadians do not earn enough money to cover a $\$ 400$ USD or $\$ 200$ CAD emergency. ${ }^{4}$ The great displacement appears to have been chiefly responsible for the economic destruction of many working-class towns, surging rates of drug abuse, deaths of despair, and declining life expectancy in the United States. Similar dynamics have been present and appear to be continuing to unfold in Canada, where life expectancy is still slowly increasing but has begun to stagnate and may be in danger of declining due to deaths of despair. ${ }^{5}$ Some commentators have argued convincingly that the great displacement has been a major driver of the populist rage that has fuelled right-wing political movements in recent years. Many elements of these movements falsely blame immigrants, progressive social attitudes, or cultural elites for the erosion of opportunities for workers who are native-born members of ethnic majorities, when the primary underlying causes of this erosion are actually technological displacement and wealthy corporate elites using their disproportionate power to enrich themselves at the expense of the rest of society. ${ }^{6}$ The political consequences of the success of right wing movements have been profound, especially in light of their proclivities to care less about addressing the climate crisis. By thus influencing climate policy, there may be enormous indirect harms of the great displacement to many of the poorest individuals in the world who are most vulnerable to the harms of climate change, as well as all life on earth. ${ }^{7}$

As I have emphasized, the great displacement is not simply a prediction about the future but a hard reality of the present and past 40 years. But its trends do seem set to continue, and indeed worsen. It has been estimated that around $40 \%$ of tasks currently performed by humans in the US and Canada could be automated to some extent using current technology. ${ }^{8}$ The Office of the President has estimated that $83 \%$ of jobs that pay less than $\$ 20$ per hour will be subject to automation or replacement in the near future. ${ }^{9}$ Suppose we set aside the fact that many experts seem to agree that it will take at most a few decades for automated trucking to displace millions of transport workers and workers in support industries like truck stops. In what has become known as the "retail apocalypse," many retail jobs are already disappearing with the rise of e-commerce. North American retailers have announced more than 9,100 store closures in 2019, after closing more than 5,000 stores in both 2017 and $2018 .{ }^{10}$

As we have seen, the great displacement has primarily involved a worsening of opportunities for blue-collar workers, and this seems likely to continue in the near future. But the trend of displacement due to automation will likely extend to a good deal of white-collar work. Even substantial parts of the jobs of lawyers and health care professionals are routine and thus seem liable to automation. ${ }^{11}$ If the economic consequences of the displacement of some of these higher-skilled white-collar workers follows those of the displacement of midskilled blue-collar workers, the result will not be massive unemployment, and the problem will not be that there

\footnotetext{
${ }^{4}$ Board of Governors of the Federal Reserve System 2018; Canadian Press 2019.

${ }^{5}$ Yang 2018; Case and Deaton 2015; Case and Deaton 2017; Lang et al. 2018.

${ }^{6}$ See e.g. Yang 2018; Stiglitz 2019; and Sunkara 2019.

${ }^{7}$ Nolt 2011; Shindell et al. 2018; IPCC 2018.

${ }^{8}$ McKinsey Global Institute 2017; Frey \& Osborne 2013; Lamb 2016

${ }^{9}$ Executive Office of the President 2016.

${ }^{10}$ Peterson 2019; Coresight Research 2019; Timmerman 2018. On the coming adoption of self-driving vehicles and its likely consequences see e.g. Yang 2018, chapter 5, pp. 45-7.

11 Yang 2018, Chapter 6; McKinsey Global Institute 2017.
} 
are no new jobs being created. The problem will be that the higher-paying new jobs will require skills that many of those displaced lack and are ill-prepared to acquire, while the accessible jobs will be lower-paying, lower-skilled jobs that many workers are competing to fill.

In light of the profundity of the continuing economic and social problems created by the great displacement for so many workers in OECD countries over the past 40 years, and the likely political and thus ecological consequences for the global poor and all life on earth, it seems reasonable to conclude that the great displacement is the most pressing immediate ethical problem with AI systems. While important, problems created by such issues as algorithmic discrimination, privacy in relation to the data used by AI systems, and how to most responsibly combine the insights of human experts and AI systems are not currently having effects that are anywhere near as harmful to as many individuals as the great displacement.

To address the problems of the great displacement, various authors and policy-makers have proposed measures to increase workers' living standards. These include the adoption of a universal basic income, increased minimum wages, and increased public investment in and access to education, as well as other social services like healthcare. They also include measures to give workers greater control over the firms for which they work, such as pro-union policies, the subsidization of workers' co-ops, and worker and community co-determination. Finally, they include investment in a Green New Deal that will provide substantial employment to workers in the process of transitioning to green energy, buildings, and agriculture. ${ }^{12}$

I will not in this paper empirically assess the relative abilities of these measures to increase the living standards of lower-income workers whose opportunities have stagnated or deteriorated. I will assume, as I think is very well empirically supported, that some such measures would be effective at improving living standards for those vulnerable to displacement without doing more harm than good. In the remainder of this paper I will argue that both left-wing and right-wing positions in political philosophy, such as John Rawls's Justice as Fairness (Rawls, A Theory) and Robert Nozick's Entitlement Theory, are committed to the conclusion that we have a duty to counteract the effects of technological displacement by undertaking some such measures to improve workers' living standards (Nozick). Hence, if parties across the political spectrum can accept the empirical reality of the problems caused by the great displacement, they are committed to agreeing that we should undertake political action to improve workers' standards of living. Perhaps surprisingly, I will argue that, if all parties can accept the empirical reality of the grave threat posed by anthropogenic climate change and the efficacy of a Green New Deal to address this threat and improve living standards, then those across the political spectrum are most strongly committed to agreeing that we should implement a Green New Deal.

\section{The Philosophical Positions: From Right to Left}

In this section I will motivate in turn the main political philosophical positions to which I will address my argument.

\footnotetext{
12 Brunn and Duka 2018; Yang 2018; Sanders 2019; Warren 2019; NDP 2019; Labour Party of the United Kingdom 2017; Wolff 2012; Sunkara 2019; Stiglitz 2019; Rifkin 2011; 2019. It should be noted that over and above their directly helping workers to share more equitably in the benefits of automation, measures to empower workers might have the additional benefits of enabling them to avoid domination, have more say over their work and societies more generally, and prevent the gains of the above-mentioned social democratic measures from being undone by the disproportionate political power of wealthy corporate interests.
} 
The first and farthest right is philosophical right-libertarianism [hereafter 'right-libertarianism ${ }^{\prime 13}$ ]. The core moral idea of right-libertarianism is that we have strong moral entitlements against being interfered with by others, so long as we are not interfering with anyone else. As right-libertarians argue, these moral entitlements seem to directly support strong moral entitlements to the fruits of our labour. For instance, suppose that you and I are both stranded on a desert island. You work hard and gather lots of coconuts, while I do not work hard and gather no coconuts. Suppose that I then appropriate half of your coconuts. My act seems relevantly like morally wrongful assault in terms of it being a harmful interference or interference with your autonomy.

Of course, in a complex multi-period economy with transfers, pre-tax income is not a simple function of work effort. But the idea of rights to non-interference seems to extend to holdings that result from voluntary transfers. Suppose that Mary works hard harvesting coconuts, and gives many of them to her partner, Martin. Kate does not work hard, and does not give any coconuts to her partner, Kevin. Suppose that Kevin then takes half of the coconuts that Mary gave to Martin. This also seems wrong in virtue of being harmful or autonomyundermining interference. Mary's voluntary work effort plausibly entitled her to the coconuts, and entitled her to transfer them to whomever she chose just as much as to consume them. Once someone like Martin legitimately acquires the coconuts through such a voluntary transfer, it seems to be just as much of a wrongful interference with his well-being or autonomy (or perhaps Mary's autonomy) to take them from him without his consent as it would have been to taken them from Mary without her consent. Nozick brings these core rightlibertarian ideas together in

\section{Nozick's Entitlement Theory of Justice in Holdings:}

i. Justice in Initial Acquisition: One is entitled to unheld things that one appropriates or creates without violating anyone else's entitlements.

ii. Justice in Transfer: One is entitled to what one receives from voluntary contracts, gifts, etc. in the absence of force and fraud.

iii. Rectification of Injustice: If i. or ii. are violated, then one is entitled to rectificatory compensation (Nozick, Ch. 7).

Nozick argues that this right-libertarian entitlement theory justifies only the coercive taxation necessary to support minarchy, or a minimal state needed to protect entitlements against interference. This would include the funds needed to support the police force, law courts, a defensive military, and the requisite administration. But an immediate problem for this position is that, if entitlements are absolute, it is unclear how we can justify taxation to support even the minimal state. Absolute entitlements would seem to support the anarcho-capitalist conclusion that no taxation to support a state is ever justified (Rothbard). But a society organized along anarcho-capitalist lines, where individuals must voluntarily join warring protective associations, would seem to secure far weaker protections of entitlements to non-interference than a society with a minimal state that has a monopoly on conventionally allowed force administered by a single legal system. It seems, moreover, just as clear that it is morally permissible to make minor infringements on entitlements to property by collecting taxes

\footnotetext{
13 'Right-Libertarianism' can be used more broadly to refer to any view according to which the role of the state in the economy should be strictly limited, even if the justification for the view is largely that strictly limiting the state will as a matter of empirical fact have the best economic results for everyone. The modifier 'philosophical' indicates that the libertarian position is held more as a matter of ethical principle and is relatively independent of any empirical economic view about the effects of state intervention or its absence. Because I am exclusively concerned with the philosophical position in the text, the modifier is not necessary.
} 
for something as important as protecting everyone's entitlements against the greatest possible interference, as it is that the principles of the entitlement theory have some moral weight to begin with.

Thus, the philosophical anarcho-capitalist view that moral entitlements to property are absolute seems to be methodologically schizophrenic when it comes to accepting or rejecting intuitions. Because it is just as plausible that property entitlements are not absolute as it is that they exist in the first place, unless some further justification is given, it is arbitrary to accept the intuition that they exist but dismiss the equally strong intuition that they can be overridden in minor ways to protect everyone's most major entitlements. But Nozick's more moderate right-libertarian stance of philosophical minarchism seems to face its own problem of arbitrariness. This is that, if it is morally permissible to make minor infringements on entitlements to property in the form of taxation for something as morally important as a state that protects everyone against the most massive violations of their entitlements, there seems to be no principled way of opposing other such minor infringements for other morally important goals. For instance, there seems to be no defensible moral line to draw between taxation to finance the minimal state and taxation to subsidize positive externalities (i.e. unintended benefits to third parties from economic activities) and other goods that are to a degree public (i.e. which do not permit the exclusion of third-parties from enjoying them and which do not cost more to provide to more individuals rather than fewer), such as physical infrastructure, knowledge, and environmental quality.

Moreover, if the aim of providing public goods is sufficiently important as to justify taxing even those who would rather keep their money than enjoy them, it is unclear why there cannot be, as it seems there are, enforceable duties of beneficence simply to benefit others. If the stakes are high enough and the costs are low enough, it seems perfectly permissible (and indeed morally required) to coerce some to help others. Consider such cases as

Coercing in Pond (inspired by Singer): You are some ways off when you see Joe about to walk past a shallow pond in which a small child is drowning. If Joe wades in and saves the child he will not ruin any of his property; he has left his shoes by where you are. But Joe is very selfish and does not even want to get his feet wet. You are too far away to get to the child in time yourself, but you can call to Joe and threaten that you will ruin his $\$ 200$ shoes if he does not save the child.

The Yacht (Unger 1996): You see a woman in the water in danger of drowning from an impending hurricane. If you go to aid her she'll be saved; if not she'll soon die. The only way to aid her is to use a motor yacht worth several million dollars, the billionaire owner of which is not on the scene and cannot be reached for permission. Saving the woman will also inflict a million dollars' worth of damage on the yacht, most of which you can't pay and won't be covered by insurance.

It seems just as clear that it is permissible to threaten Joe with the destruction of his shoes and to take and damage the motor yacht without its owner's permission to save the child and woman as it is that the principles of Nozick's entitlement theory carry any moral weight. This seems, moreover, to be justified by the following principle, which is just as directly plausible as those of the entitlement theory

The Enforceability of Easy Important Beneficence: If someone or her property can prevent enormous harm to others at relatively trivial cost to herself (and everyone else), then all else held equal it is permissible to apply at least light coercion to get her to do so or use her property without her permission to do so.

A moderate philosophical theory of justice in holdings might thus move somewhat to the left of rightlibertarianism by continuing to accept the plausible principles of Nozick's entitlement theory as having some weight, but taking this weight to be overridable by the importance of such things as providing substantial public goods and benefits to others when the costs to those who are coerced or taxed are relatively quite low. But 
one might be tempted to move further to the left if one is troubled by the further consideration that rightlibertarianism seems to require us to allow there to be massive inequalities of opportunity. It seems to require us to allow there to be situations in which two individuals might be equally talented and hardworking, but because one happens to be born into a disadvantaged situation, she has much poorer life prospects. One might think instead that, as Rawls (Theory, 87) suggests, we should "set up the social system so that no one gains or losses from his arbitrary place in the distribution of natural assets or his initial position in society without giving or receiving compensating advantages in return."

The core moral idea of this substantially farther left idea about justice in holdings, as articulated by Rawls (Theory, 54), is that "all social values - liberty and opportunity, income and wealth, and the social bases of selfrespect - are to be distributed equally unless an unequal distribution of any, or all, of these values is to everyone's advantage." One might initially be inclined to think that this core idea does not give adequate weight to the moral relevance of work effort and risk-taking in acquiring or creating previously unheld or non-existent wealth, and the consequent freedom one should have to dispose of this wealth as one chooses. But Rawls seeks to undermine the idea that work effort and risk-taking should have any moral relevance over and above considerations of which institutions will be to everyone's advantage by appropriately incentivizing such wealthcreating acts. Rawls (Theory, 89) argues that, because an individual's propensities to exert greater work effort (and take greater risks) ultimately trace to factors beyond her control such as her early environment and native dispositions, she has no moral entitlement to greater rewards because of them over and above the rewards that may justifiably accrue to them due to its being to everyone's advantage to incentivize their manifestation to some degree.

Rawls further articulates this philosophically left-wing theory of justice in holdings in

\section{Rawls's Justice as Fairness:}

i. Each individual should have as extensive a set of basic liberties as is compatible with the same set of basic liberties for everyone else (Principle of Equal Liberty)

ii. Social and economic inequalities

a. Must be attached to positions that are effectively open to all (Principle of Fair Equality of Opportunity), and

b. Must be to everyone's advantage - in particular they must be to the greatest benefit of the least advantaged (Difference Principle) (Rawls, Ch. 2)

I believe that Rawls's basic idea that social and economic inequalities stand in need of justification by considerations of what will be to the advantage of everyone including the least advantaged appropriately articulates a key commonality in basic philosophical thinking among most who hold substantially left-wing political positions. Some moderately progressive liberals believe that the least advantaged are most benefitted by a state that protects basic personal entitlements to safety, political freedom, and association; subsidizes positive externalities; penalizes negative externalities; and employs progressive taxation to fund a few social services such as primary and secondary education, unemployment insurance, and modest assistance to the poor, disabled, and elderly. Social democrats believe the least advantaged are most benefitted by a state that does this but also uses progressive taxation to fund a more robust set of social services, such as universal healthcare, post-secondary education, childcare, housing, and employment. Many socialists believe that the least advantaged are most benefitted by a state that provides these protections and services but also ensures that the workers control the means of production, through either the public ownership of the central institutions involved in important industries beyond health insurance and housing such as banking, large-scale energy 
generation, and information technology industries that tend to support natural monopolies; or insuring the ownership and democratic control of firms by all of those who work for them and the wider community. Leftist anarchists tend to believe that the least advantaged will be most benefitted by a society that provides all of these protections, social services, and democratic cooperative institutions, but without the hierarchical and coercive apparatus of a state - which might seem most feasible only after technological innovation has ushered in a post-scarcity era. ${ }^{14}$ There may be substantial philosophical differences among such individuals on the left side of the political spectrum in terms of the rationale for the value and kinds of equality, social and economic goods, and advantage that are taken to be most important. But these differences should not matter to the general thrust of my argument.

\section{The Argument: From Left to Right}

I have thus outlined three basic political philosophical positions. Going in reverse order from above, we first have a left-wing position that accepts Justice as Fairness and the Difference Principle. On this view we should take political action that will most benefit the least advantaged. Second, we have a moderate position that accepts the legitimacy of light coercion in the form of taxation to subsidize positive externalities and the enforceability of easy important beneficence but draws the line there. On this view we should take political action to prevent serious harm to the vulnerable if the burden to those disadvantaged by this action is quite small in comparison to the harm prevented. Third, we have a pure right-libertarian position that tries to treat the principles of Nozick's entitlement theory as absolutely as possible. The more moderate version of this view is minarchist and allows the principles to be overridden only to collect taxes to pay for a minimal state that protects everyone's moral entitlements. The more extreme version of this view takes the principles of the entitlement theory to be absolute and embraces the anarcho-capitalist conclusion that we may not impose taxes on the unwilling even to support a minimal state.

My thesis is that all of these positions are committed to the conclusion that we should undertake political action that addresses the great displacement by increasing the living standards of disadvantaged workers.

The argument for this conclusion is most straightforward in the case of the left-wing position. Those most harmed by the great displacement in OECD countries like Canada and the United States are the poorest bluecollar and low-skilled workers, who are bidding down wages in the far fewer moderate-skilled jobs and the more tenuous low-skilled jobs, exiting the labour force, finding themselves unable to cover emergency expenses, living in desolated communities, and in danger of turning to drugs and dying deaths of despair. If one takes into account the indirect effects of the great displacement helping to elect right-wing governments that are more reluctant to address the climate and ecological emergency, then those most harmed globally may be the global poor who are most vulnerable to the harms of climate change. These individuals face potentially lethal drought, flooding, extreme poverty, disease, physical displacement, and other disruptions. Thus, raising the living standards of the lower income OECD workers who are most affected by the great displacement will directly help the least advantaged in OECD countries, and indirectly help the least advantaged globally by helping to elect more progressive politicians who will do more to address the climate emergency. Because such political action will benefit the least advantaged, it is, according to the left-wing position, something we have a duty to undertake. ${ }^{15}$

\footnotetext{
${ }^{14}$ See for instance Sunkara 2019; Wolff 2012; Bookchin 1971; and Bastani 2019.

${ }^{15}$ It thus does not matter whether the left-wing position understands the requirement to take political action to benefit the least advantaged as pertaining to the least advantaged in the polity in question or the least advantaged its actions can affect. There is some controversy among
} 
The argument for the duty to take political action to increase living standards is also relatively straightforward on the moderate position. Mitigating the above discussed hardships to the least advantaged OECD workers and indeed the global poor through taxes or losses of economic power that fall most heavily on top earners is a way of preventing enormous harm to many less advantaged individuals at relatively trivial cost to the top earners. Such policies are also likely to have positive externalities through such effects as lowering crime rates and increasing aggregate demand for goods and services (since the poorer spend more income). ${ }^{16}$ This redistribution of wealth and power is thus an instance of the kind of enforcement of easy important beneficence and of light coercion in the form of taxation to subsidize important positive externalities that the moderate position holds we have a duty to undertake.

It is most difficult to make the case for the duty to increase living standards on the right-libertarian position (minarchist or anarcho-capitalist). Still, I think that there are three compelling arguments that can be offered even to relatively pure libertarians. The first concerns the rectification of past injustice. If we trace any property holding back far enough, we will find that it at some point stems from force and fraud. Plausibly, there is a moral imperative to make some restitution for this past injustice if it is possible. At the very least, we should not allow anyone to suffer destitution as a result of past force or fraud if we can avoid it. Suppose, for instance, that baby Barbara was orphaned and the inheritance that her parents left to support her was stolen by Andrew and added to the already substantial trust fund of his unwitting son Aaron. It certainly seems that we should not allow Barbara to die from poverty-related causes if we can determine what happened, reclaim the inheritance from Aaron, and use it to support Barbara.

Most vulnerable workers threatened with destitution from the great displacement probably would not be had their ancestors not been at some point subjected to force or fraud, whether they were medieval peasants whose commons were enclosed, slaves who were captured and forced to work for centuries, or members of first-nations whose land was stolen relatively recently. As such, increasing the living standards of vulnerable workers is arguably necessary to prevent them from suffering destitution as a result of a lack of rectification of past injustice. There is, of course, no way to know with certainty who has been advantaged or disadvantaged by each of the countless acts of past injustice that have taken place ever since our ancestors were moral agents. The idea would be that the balance of expected justice from raising the incomes of the vulnerable and thus preventing anyone from suffering destitution as a result of past injustice outweighs the expected injustice from taxing the relatively well-to-do beyond what they have received as a result of past injustice. ${ }^{17}$

A slightly less historically complicated argument from considerations of the rectification of past injustice stems from the fact that much AI research has actually been publicly funded (Stiglitz). It has thus been financed in part by taxes on the meager earnings of the majority of vulnerable workers and their ancestors. Since this went beyond taxes collected to finance a minimal state, right-libertarians are committed to thinking that this collection and use of taxes constituted wrongful theft. The vulnerable workers are thus owed restitution from the state,

\footnotetext{
proponents of Justice as Fairness (as well as members of the center and left side of the political spectrum more generally) about how a polity should thus balance the interests of its members against those of individuals outside of it. Authors like Rawls (1999) take the difference principle to apply only to a polity's treatment of its members, while authors like Thomas Pogge (1989) take it to apply to anyone in the world affected by the polity's actions. But even Rawls (1999: 37), like the moderates discussed below, would hold that members of OECD countries have a duty to take political action to prevent the global poor from suffering massively from climate change - including by making things tolerable for less advantaged members of OECD countries so they do not feel compelled to vote for right-wing politicians who fail to act on climate change. Moreover Rawls (1999: 37), like the moderates and right-libertarians discussed below, would acknowledge that members of OECD countries do not have a right to inflict harms on the global poor in exchange for much smaller benefits, as we do through our GHG emissions and other forms of ecological destruction, and would thus take concern for the global poor to be a sufficient reason to enact a Green New Deal to prevent our unjustly interfering with them.

16 See e.g. Yang 2018 and Stiglitz 2019.

17 Nozick 1974; Rybak 2015.
} 
or from the higher earners who are benefitting disproportionately from the AI technology that the state used the confiscated earnings or inheritance of the vulnerable workers to create, in the absence of which the vulnerable workers are threatened with stagnant or declining living standards. Measures to increase the living standards of vulnerable workers, facilitated by transfers of income or power from higher earners who have benefitted most from AI, could help make this restitution.

A second argument that even right-libertarians are committed to a duty to increase the living standards of workers disadvantaged by the great displacement concerns the "Lockean Proviso." The right-libertarian position can seem most plausible if it incorporates a moral constraint on the initial acquisition of unowned things that prevents those who come later from being unduly disadvantaged by that acquisition. As Locke put the idea, the appropriation of an unowned thing gives someone a legitimate entitlement to it if (and perhaps only if) "there was still enough (and as good) left for others" (Locke, Ch. 5 para 33). To motivate such a proviso, consider the hypothetical case of

Shipwreck. 5 ship-wrecked individuals are tossed from their ship, and are swimming towards a desert island with plenty of coconuts on which to live. One of them, Bill, happens to be tossed closest. When he arrives on the island he appropriates the whole thing (claims it, puts up a fence, mixes a little labour with it, etc.). He then tells the other four that he will only allow them to avoid drowning by entering and staying on his island if they agree to terrible conditions, such as becoming his slaves, cutting off or cutting out their limbs or internal organs, or some such.

Surely Bill is not entitled by the mere fact that he happened to arrive on the island first to subject those who happened to arrive later to this horrible choice. At the very least, the following version of the Proviso seems plausible

The Sufficiency Proviso: When one can with relative ease give others the opportunities they need to escape destitution, one is not entitled to avoid doing so if the resources one has trace to an initial acquisition that did not leave them the resources needed to escape destitution. ${ }^{18}$

Higher earners who have benefitted most from AI technology can with relative ease give the majority of lesswell-off workers who are threatened with destitution the resources they need to escape destitution. If they do not do this, their holdings will trace to an initial acquisition that did not leave these workers the resources they needed to escape destitution. So, the sufficiency proviso requires higher earners to give the majority of vulnerable workers what they need to escape destitution by paying taxes or empowering workers to increase their living standards.

A final argument is that even right-libertarians are committed to the conclusion that we should take political action to institute a Green New Deal in order to prevent unjust maleficence. Like the left-wing and moderate positions, right-libertarianism does not allow us to inflict harm on others to obtain only lesser benefits to ourselves, and it allows others to use force to prevent us from doing so. Most libertarians maintain that each individual owns herself, that harming an individual without her consent thus violates her property rights or entitlements to her holdings, and that coercively preventing such harm is thus an instance of legitimate force used to protect entitlements. ${ }^{19}$ But our greenhouse gas emissions and other forms of ecological destruction inflict harms upon others, including especially the global poor, and thus interfere with their entitlements. As such, others are justified in preventing us from inflicting these climate harms by coercive means. If the most

\footnotetext{
${ }^{18}$ See e.g. Simmons 1993; Mack 1995; Rybak 2015; and Wendt 2017.

${ }^{19}$ See e.g. van der Vossen 2019.
} 
effective such means include taxing us to pay for a Green New Deal to transition to green energy, buildings and agriculture, which along the way provides employment to and increases the living standards of lower income OECD workers immiserated by the great displacement, then political actors are justified in doing so.

Drew Shindell and colleagues estimate that if we keep emitting greenhouse gases at our current rate rather than transition to green energy and limit temperature rise to 1.5 degrees $C$, we will have caused 150 million more deaths by 2100 (Shindell et al.). John Nolt similarly estimates that the average US citizens' lifetime emissions of 1,840 tonnes of C02 equivalent can be expected to cause 1-2 deaths. Our lethal ecologically destructive activities extend beyond using fossil fuels to power our transportation, electronics, and home heating and cooling (Nolt). Animal agriculture is, even on conservative estimates, responsible for at least 14.5 $\%$ of all GHG emissions, more than all transportation exhaust combined, uses up to 20 times more land than a vegan diet, and is the leading cause of habitat destruction, desertification, ocean dead zones, water pollution, and species extinction. ${ }^{20}$ Growing crops and clearing land to feed to farmed animals only to get a tiny amount of energy back from taking their secretions, killing them, and eating their corpses is an inherently inefficient process which squanders resources and generates a great deal of waste, including but not limited to greenhouse gasses. Consequently, as Joseph Poore, author of the most comprehensive study of the environmental impacts of food production across a wide range of agricultural systems, reports, "A vegan diet is probably the single biggest way to reduce your impact on planet Earth, not just greenhouse gases, but global acidification, eutrophication, land use and water use" (Carrington).

It is true that any given act of consuming animal products or otherwise causing greenhouse gas emissions can seem very unlikely to cause any harm - including to the farmed animals, who have already been killed. But as authors like Alastair Norcross, Shelly Kagan, Christopher Morgan-Knapp, and Charles Goodman have argued, our animal product purchases and other activities that generate greenhouse gasses do have small chances of crossing thresholds in the price and climate systems that cause substantial harm. ${ }^{21}$ Moreover, as David Sobel has convincingly argued, any plausible form of right-libertarianism needs to acknowledge entitlement-generated reasons to avoid these kinds of risks of harm, proportional to their expectation of harm, that can make them unjust when their social benefits are comparatively small. This, for instance, seems needed for right-libertarians to be able to justify forcibly preventing others from playing Russian Roulette with a many-chambered revolver pointed at our heads just for fun (Sobel).

Because the expected harm of our greenhouse gas emissions can be has high as 1-2 human lives, rightlibertarians are committed to the conclusion that others are justified in preventing us from engaging in these emissions through such lightly coercive measures as taxes to discourage fossil fuel and animal product consumption, encourage the use of renewable energy and plant-based alternatives, and finance a Green New Deal that will usher in renewable energy and plant-based food systems. ${ }^{22}$ Paying for this transition to green energy and agriculture ${ }^{23}$ will require hiring a great number of semi-skilled, mid-skilled, and unskilled workers to construct renewable energy generation sites, retrofit buildings, construct new green infrastructure, participate in more labour-intensive forms of agriculture, and help rewild and plant trees on land freed up by a

\footnotetext{
${ }^{20}$ FAO UN 2013; Oppenlander 2013; Poore and Nemecek 2018; Shepon et al. 2018; Springmann et al. 2018

${ }^{21}$ Norcross 2004; Kagan 2011; Morgan-Knapp and Goodman 2015.

${ }^{22}$ It should also be noted that others are more than justified in the non-coercive measures of simply removing subsidies to fossil fuel and animal agriculture industries. These subsidies should be especially outrageous to right-libertarians, as they not only violate our entitlements by taxing us to pay for things to no good social end, but in fact violate our entitlements to pay for great social ills that further violate the entitlements of others.

${ }^{23}$ Which will be plant-based but perhaps involve some growing of animal products from cell cultures; on this see e.g. Bastani 2019.
} 
transition to a plant-based food system so as to best sequester carbon. ${ }^{24}$ This Green New Deal will thus have the effect of substantially increasing living standards among the majority of workers suffering from the great displacement. Even if right-libertarians thought the state would not be justified in taxing us solely in order to increase the living standards of workers suffering from the great displacement, the theory certainly allows us to increase their living standards as a nice side-effect of coercing us into paying for a Green New Deal to prevent us from inflicting massive harm on others by continuing to emit GHGs and otherwise destroy the environment at our current rates. ${ }^{25}$

\section{Conclusion: How Al can Aid the Solution of its Own Greatest Immediate Problem}

I have thus argued that whatever philosophical position we adopt on the political spectrum, from left-wing, to moderate, to right-libertarian, we are committed to the conclusion that we should take political action that will increase the living standards of workers who are disadvantaged by the great displacement. The case for crossspectrum philosophical support for such action is particularly strong in the case of the Green New Deal, which will not only increase the living standards of disadvantaged workers but prevent us from inflicting massive climate and ecological harms on millions of others.

The Green New Deal will do this by financing a just transition away from industries that are destroying the planet, like fossil fuels and animal agriculture, and towards new industries like green energy, green agriculture, and clean growth industries like AI itself. Jeremy Rifkin (Third Industrial Revolution; New Green Deal) argues that green energy and AI technology can compliment each other by spurring a "third industrial revolution." The economy of this revolution will function smoothly, greenly, and democratically with the integration of the traditional internet, the green energy internet, and the automated transportation logistics internet utilizing sensors embedded in products constituting an "internet of things," all powered by AI technology. But we can only achieve this if we take measures now to transition to green energy and agriculture, improve the living standards of those suffering from the great displacement, and make sure that no one is shut out from this bright future.

\footnotetext{
24 Rifkin 2011; Rifkin 2019, Oppenlander 2013; Bastin et al. 2019.

25 This argument for increasing the living standards of those immiserated by the great displacement as a side-effect of preventing maleficence is amplified if libertarians accept, as I think they should, that we have enforceable duties not to harm non-human animals. It seems clear that we have enforceable duties not to harm sentient humans who are no more capable of moral or deliberative agency than sentient non-human animals, such as human infants and profoundly intellectually disabled humans. But the only thing that distinguishes some of these humans from intellectually comparable non-human animals is bare biological species membership, which amounts to nothing more than something like the genetic potential to interbreed with certain individuals to produce fertile offspring, certain physical body characteristics, certain differences in genes, or having descended in a certain way from certain distant biological ancestors. These traits look just as irrelevant to whether we owe someone enforceable duties not to harm her as her biological sex or ethnicity. So just as we should hold that young human children and profoundly intellectually disabled humans have enforceable entitlements not to be harmed, we should conclude that non-human animals have these entitlements too (see e.g. Singer 1975; McMahan 2002; Norcross 2004; Vallentyne 2002). Because there are several times more sentient non-human animals on the planet than humans (see e.g. Tomasik 2018), most of whom are likely to be more vulnerable to the harms of climate change and ecological devastation, this simply increases the strength of the entitlement-generated reasons to prevent climate and ecological devastation via the funding of a Green New Deal. Similarly, while enforceable duties not to harm non-human animals would seem to justify an outright ban on the slaughter and other harms involved in the production of animal products, the enactment of such a ban is unlikely to be politically feasible in the absence of a sustained transition to a plant-based food system. An agricultural Green New Deal that among other things facilitates the transition to such a plant-based food system would thus seem to be required as the most feasible way to enforce duties against harming non-human animals. In both cases the Green New Deal, endorsed by right-libertarianism as a way of enforcing our duties not to harm non-human animals, has the welcome side-effect of increasing the living standards of workers immiserated by the great displacement.
} 


\section{References}

Acemoglu, Daron and David Autor. (2011). Skills, Tasks and Technologies: Implications for Employment and Earnings, In D. Card and O. Ashenfelter (eds.), Handbook of Labor Economics, Vol. 4B (San Diego, CA: North Holland), 1043-1171.

Acemoglu, Daron and Pascual Restrepo. (2017). Robots and Jobs: Evidence from US Labor Markets. NBER Working Paper, No. 23285, March 2017. Available at: https://www.nber.org/papers/W23285.pdf.

Bastani, Aaron. (2019). Fully Automated Luxury Communism: A Manifesto. London: Verso.

Bastin, Jean-Francois, Yelena Finegold, Claude Garcia, Danilo Mollicone, Marcelo Rezende, Devin Routh, Constantin Zohner, and Thomas Crowther. (2019). The Global Tree Restoration Potential. Science 365(6558): 76-79. DOI: 10.1126/science.aax0848

Board of Governors of the Federal Reserve System. (2018). Report on the Economic Well-Being of U.S. Households in 2017. May, 2018. Available at: https://www.federalreserve.gov/publications/files/2017report-economic-well-being-us-households-201805.pdf.

Bookchin, Murray. (1971). Post-Scarcity Anarchism. Pheonix: Ramparts Press.

Bruun, Edvard and Alban Duka. (2018). Artificial Intelligence, Jobs and the Future of Work: Racing with the Machines. Basic Income Studies 13(2): 1-15, DOI: 10.1515/bis-2018-0018.

Canadian Press. (2019). 46\% of Canadians $\$ 200$ or Less Away from Financial Insolvency: Poll. Posted: Jan 21, 2019 11:07 AM MT. Available at: https://www.cbc.ca/news/canada/calgary/200-financial-insolvency-20191.4986586.

Carrington, Damian. (2018). Avoiding Meat and Dairy is 'Single Biggest Way' to Reduce Your Impact on Earth. The Guardian, May 31, 2018.

Case, Anne, and Angus Deaton. (2015). Rising Morbidity and Mortality in Midlife Among White Non-Hispanic Americans in the 21st Century. Proceedings of the National Academy of Science [PNAS] 112(49): 1507815083. Available at: https://www.pnas.org/content/112/49/15078.

------. Mortality and Morbidity in the 21st Century. (2017). Brookings Papers on Economic Activity, Spring 2017: 397-476. Available at: https://www.ncbi.n/m.nih.gov/pmc/articles/PMC5640267/.

Coresight Research. (2019). Weekly US and UK Store Openings and Closures Tracker 2019. Available at: https://coresight.com/research/weekly-us-and-uk-store-openings-and-closures-tracker-2019-week-15freds-to-shut-159-stores-in-the-uk-debenhams-enters-administration/.

Devaraj, Srikant, Michael Hicks, Emily Wornell, and Dagney Faulk. (2017). How Vulnerable are American Communities to Automation, Trade and Urbanization? Center for Business and Economic Research, Ball State University. Available at: https://projects.cberdata.org/123/how-vulnerable-are-americancommunities-to-automation-trade-urbanization.

DeSilver, Drew. (2018). For Most U.S. Workers, Real Wages Have Barely Budged in Decades. Pew Research Centre, August 7, 2018, available at: https://www.pewresearch.org/fact-tank/2018/08/07/for-most-usworkers-real-wages-have-barely-budged-for-decades/.

Executive Office of the President. (2016). Artificial Intelligence, Automation, and the Economy. December 2016. Available at: https://obamawhitehouse.archives.gov/sites/whitehouse.gov/files/documents/ArtificialIntelligence-Automation-Economy.PDF.

Food and Agriculture Organization of the United Nations [FAO UN]. (2013). Tackling Climate Change Through Livestock: A Global Assessment of Emissions and Mitigation Opportunities. Rome: FAO. Available at: http://www.fao.org/3/a-i3437e.pdf.

Frey, Carl and Michael Osborne. (2017). The Future of Employment: How Susceptible are Jobs to Computerisation? Technological Forecasting \& Social Change 114 (2017): 254-280. 
Green, David and Benjamin Sand. (2015). Has the Canadian Labour Market Polarized? In Income Inequality: The Canadian Story, edited by David Green, W. Craig Riddell, and France St-Hilaire (Institute for Research on Public Policy, 2015), pp. 217-227. Available at: https://irpp.org/research/income-inequality-thecanadian-story/.

Hicks, Michael and Srikant Devaraj. (2015). The Myth and the Reality of Manufacturing in America. Conexus, Indiana: Ball State University Centre for Business and Economic Research. Available at: https://conexus.cberdata.org/files/MfgReality.pdf.

Intergovernmental Panel on Climate Change [IPCC]. (2018). Global Warming of $1.5^{\circ} \mathrm{C}$ : An IPCC Special Report (Geneva: World Meteorological Organization, 2018). Available at: https://www.ipcc.ch/sr15/.

International Monetary Fund [IMF]. (2017). World Economic Outlook: Gaining Momentum? Washington, April 2017. Available at: https://www.imf.org/en/Publications/WEO/Issues/2017/04/04/world-economicoutlook-april-2017.

James Ketcheson, Natalia Kyui, and Benoit Vincent. (2017). Labour Force Participation: A Comparison of the United States and Canada. Staff Analytical Notes 17-9, Bank of Canada. Available at: https://www.bankofcanada.ca/wp-content/uploads/2017/07/san2017-9.pdf.

Kagan, Shelly. (2011). Do I make a difference? Philosophy and Public Affairs, 39: 105-41.

Katz, Lawrence and Alan Krueger. (2016). The Rise and Nature of Alternative Work Arrangements in the United States, 1995-2015. NBER Working Paper, No. 22667, September 2016. Available at: https://www.nber.org/papers/W22667.pdf.

Krusell, Per, Lee Ohanian, Jose-Victor Ríos-Rull, and Giovanni Violante. (2000). Capital-Skill Complementarity and Inequality: A Macroeconomic Analysis. Econometrica 68 (5): 1029-1053

Labour Party of the United Kingdom. (2017). For the Many, Not the Few. The Labour Party Manifesto 2017.

Available at: https://labour.org.uk/wp-content/uploads/2017/10/labour-manifesto-2017.pdf.

Lamb, Creig. (2016). The Talented Mr. Robot: The Impact of Automation on Canada's Workforce. Brookfield Institute for Innovation and Entrepreneurship, June 2016. Available at: https://brookfieldinstitute.ca/report/the-talented-mr-robot/.

Lang, Justin, Samiah Alam, Leah Cahill, Aaron Drucker, Carolyn Gotay, Jeanne Kayibanda, Nicole Kozloff, Kedar Mate, Scott Patten, Heather Orpana. Global Burden of Disease Study trends for Canada from 1990 to 2016. Canadian Medical Association Journal [CMAJ], 190(44): E1296-E1304. DOI: doi: 10.1503/cmaj.180698.

Locke, John. (1690). Second Treatise of Government. Reprinted with an introduction by C. B. Macpherson (ed.), Indianapolis: Hackett Publishing Company, 1980.

Mack, Eric. (1995). The Self-Ownership Proviso: A New and Improved Lockean Proviso. Social Philosophy and Policy 12: 186-218.

McKinsey Global Institute. (2017). A Future That Works: Automation, Employment, and Productivity. January 2017. Available at: https://www.mckinsey.com/featured-insights/digital-disruption/harnessing-automationfor-a-future-that-works.

McMahan, Jeff. (2002). The Ethics of Killing: Problems at the Margins of Life. New York: Oxford University Press.

Meckstroth, Daniel. (2013). Where Did All the Displaced Manufacturing Workers Go? Geartechnology, August 2013, 10-11. Available at:

https://www.geartechnology.com/issues/0813x/displaced_manufacturing_workers.pdf.

Morgan-Knapp, Christopher, and Charles Goodman. (2015). Consequentialism, Climate Harm, and Individual Obligations. Ethical Theory and Moral Practice, 18: 177-90. 
New Democratic Party of Canada. (2019). A New Deal for People: New Democrats'Commitments to You. Official New Democratic Party of Canada website. Available at: https://www.ndp.ca/commitments.

Nolt, John. (2011). How Harmful Are the Average American's Greenhouse Gas Emissions? Ethics, Policy and Environment, 14 (2011), 3-10.

Norcross, Alastair. (2004). Puppies, Pigs, and People: Eating Meat and Marginal Cases. Philosophical Perspectives, 18: 229-45.

Nozick, Robert. (1974). Anarchy, State, and Utopia. New York: Basic Books.

Oppenlander, Richard. (2013). Food Choice and Sustainability: Why Buying Local, Eating Less Meat, and Taking Baby Steps Won't Work. Minneapolis, MN: Langdon Street Press.

Organisation for Economic Co-operation and Development [OECD]. (2017). OECD Employment Outlook 2017, OECD Publishing, Paris. Available at: https://doi.org/10.1787/empl_outlook-2017-en.

Peterson, Hayley. (2019). More than 9,100 Stores are Closing in 2019 as the Retail Apocalypse Drags on Here's the Full List. Business Insider, November 12, 2019. Available at: https://www.businessinsider.com/stores-closing-in-2019-list-2019-3.

Pogge, Thomas. (1989). Realizing Rawls. Ithaca, NY: Cornell University Press.

Poore, Joseph. and Thomas Nemcek. (2018). Reducing Food's Environmental Impacts Through Producers \& Consumers, Science 360: 987-992, DOI: 10.1126/science.aaq0216.

Rawls, John. (1971). A Theory of Justice. Cambridge, MA: Harvard University Press.

------. 1999. The Law of Peoples. Cambridge, MA: Harvard University Press.

Rifkin, Jeremy. (1995). The End of Work: The Decline of the Global Labor Force and the Dawn of the PostMarket Era. New York: G.P. Putnam's Sons.

-------. (2011). The Third Industrial Revolution: How Lateral Power is Transforming Energy, the Economy, and the world. New York: Plagrave MacMillan.

------. (2019). The Green New Deal: Why the Fossil Fuel Civilization Will Collapse by 2028, and the Bold Economic Plan to Save Life on Earth. New York: St. Martin's Press.

Rothbard, Murray. (1973). For a New Liberty: The Libertarian Manifesto. New York: The Macmillan Co.

Rybak, David. (2015). Negative Liberty and Freedom from Coercion in the 21st Century: The Classical Liberal Case for a Basic Income. Honors Thesis, University of Alberta.

Sanders, Bernard. (2019). Bernie Sanders on the Issues. Official campaign website. Available at: https://berniesanders.com/issues/.

Shepon, Alon, Gideon Eshel, Elon Noor, and Ron Milo (2018). The Opportunity Cost of Animal Based Diets Exceeds All Food Losses. Proceedings of the National Academy of Science [PNAS] 115(15): 3804-3809. DOI: 10.1073/pnas.1713820115.

Shindell, Drew, Greg Faluvegi, Karl Seltzer, and Cary Shindell. (2018). Quantified, Localized Health Benefits of Accelerated Carbon Dioxide Emissions Reductions. Nature Climate Change 8: 291-295. DOI: 10.1038/s41558-018-0108-y.

Simmons, A.J. (1993). On the Edge of Anarchy. Princeton: Princeton University Press.

Singer, Peter. (1972). Famine, Affluence, and Morality, Philosophy and Public Affairs 1: 229-243.

-------. (1975). All Animals are Equal. In Peter Singer, Animal Liberation, New York: Harper Collins.

Sobel, David. (2013). Self-Ownership and the Conflation Problem. In Mark Timmons (ed.), Oxford Studies in Normative Ethics, Volume 3, Oxford: Oxford University Press, 98-122.

Statistics Canada. (2015). Minimum wage in Canada since 1975. Available
at: https://www150.statcan.gC.ca/n1/pub/11-630-x/11-630-x2015006-eng.htm.

Stiglitz, Joseph. (2019). People, Power, and Profits: Progressive Capitalism for an Age of Discontent. New York: 
W.W. Norton \& Company.

Sunkara, Bashkar. (2019). The Socialist Manifesto: The Case for Radical Politics in an Era of Extreme Inequality. New York: Basic Books.

Timmerman, Michael. (2018). These major retailers have closed more than 5,000 stores in 2017. Clark, September 6, 2018. Available at: https://clark.com/shopping-retail/major-retailers-closing-2017/.

Tomasik, Brian, (2018). How Many Wild Animals Are There? Available at: http://reducing-suffering.org/howmany-wild-animals-are-there/. [accessed 10 January 2019]

Trading Economics. (2019). Canada Unemployment Rate, United States Unemployment Rate, Canada Labor Force Participation Rate, United States Labor Force Participation Rate. Accessed May 7, 2019. Available at: https://tradingeconomics.com/

Tyson, Laura and Michael Spence. (2017). Exploring the Effects of Technology on Income and Wealth Inequality. In After Piketty: The Agenda for Economics and Inequality, edited by Heather Boushey, J. Bradford DeLong, and Marshall Steinbaum, Cambridge: Harvard University Press.

Unger, Peter. (1996). Living High and Letting Die: Our Illusion of Innocence. New York: Oxford University Press. United Steel Workers. (2019). What Happened to Real Wage Growth? February 1, 2019. Available at:

https://www.usw.ca/news/media-centre/articles/2019/what-happened-to-real-wage-growth.

Vallentyne, Peter. (2002). Equality and the Duties of Procreators. In David Archard and Colin Macleod (eds.), Children and Political Theory. Oxford: Oxford University Press.

van der Vossen, Bas. (2019). Libertarianism. In Edward Zalta (ed.), The Stanford Encyclopedia of Philosophy (Spring 2019 Edition), URL = <https://plato.stanford.edu/archives/spr2019/entries/libertarianism/>.

Warren, Elizabeth. (2019). What Elizabeth Will Do. Official campaign website. Available at: https://elizabethwarren.com/plans.

Wendt, Fabian. (2017). The Sufficiency Proviso. In Jason Brennan, Bas Van der Vossen, and David Schmidtz (eds.), The Routledge Handbook of Libertarianism, London: Routledge, pp. 169-183.

Wolff, Richard. (2012). Democracy at Work: A Cure for Capitalism. Chicago: Haymarket Books.

Yang, Andrew. (2018). The War on Normal People: The Truth About America's Disappearing Jobs and Why Universal Basic Income Is Our Future. New York: Hachette Books. 